\title{
Origin and composition of sediment organic matter in a coastal semi-enclosed ecosystem: An elemental and isotopic study at the ecosystem space scale
}

\author{
S. Dubois ${ }^{\text {a,* }}$, N. Savoye ${ }^{\text {a }}$, A. Grémare ${ }^{\text {a }}$, M. Plus ${ }^{\text {b }}$, K. Charlier $^{c}$, A. Beltoise ${ }^{\text {a }}$, H. Blanchet ${ }^{\text {a }}$ \\ a UMR 5805 EPOC, Université Bordeaux 1, CNRS, Station Marine d'Arcachon, 2 rue du Professeur Jolyet, 33120 Arcachon, France \\ b Ifremer, LER/AR, 1 Quai du Commandant Silhouette, 33120 Arcachon, France \\ c UMR 5805 EPOC, Université Bordeaux 1, CNRS, Site de Talence, Avenue des Facultés, 33405 Talence cedex, France
}

\section{A R T I C L E I N F O}

\section{Article history:}

Received 27 May 2011

Received in revised form 18 September 2011

Accepted 9 October 2011

Available online 18 October 2011

\section{Keywords:}

Sediment organic matter

Primary producers

$\mathrm{C}$ and $\mathrm{N}$ stable isotopes

Zostera noltii

Arcachon Bay

\begin{abstract}
A B S T R A C T
The origin and composition of sediment organic matter (SOM) were investigated together with its spatial distribution in the Arcachon Bay - a macrotidal lagoon that shelters the largest Zostera noltii meadow in Europe - using elemental and isotopic ratios. Subtidal and intertidal sediments and primary producers were both sampled in April 2009. Their elemental and isotopic compositions were assessed. Relative contributions of each source to SOM were estimated using a mixing model. The SOM composition tended to be homogeneous over the whole ecosystem and reflected the high diversity of primary producers in this system. On average, SOM was composed of $25 \%$ of decayed phanerogams, $19 \%$ of microphytobenthos, $20 \%$ of phytoplankton, $19 \%$ of river SPOM and $17 \%$ of macroalgae. There was no evidence of anthropogenic N-sources and SOM was mainly of autochthonous origin. None of the tested environmental parameters - salinity, current speed, emersion, granulometry and chlorophyll $a$ - nor a combination of them explained the low spatial variability of SOM composition and characteristics. Resuspension, mixing and redistribution of the different particulate organic matters by wind-induced and tidal currents in combination with shallow depth probably explain the observed homogeneity at the whole bay scale.
\end{abstract}

(C) 2011 Elsevier B.V. All rights reserved.

\section{Introduction}

Coastal ecosystems represent $6 \%$ of earth and $8.5 \%$ of marine biomes (Costanza et al., 1997). Profuse and renewed amounts of organic matter and nutrients originating from the watersheds spark off high biological productivity in coastal zones. High primary production in these zones is associated with a wide diversity of primary producers. Shallow depths and tides allow the development of macrophytes such as kelp forests (Mann, 1973), salt marshes (Adam, 1990), mangroves (Kathiresan and Bingham, 2001 ) and seagrass beds (Duarte, 1991), which constitute an originality of coastal ecosystems as compared to oceanic ones, where primary production is dominated by phytoplankton.

Among these primary producers, seagrass meadows are prominent components of the littoral zone. Green and Short (2003) estimated that the total worldwide surface area of these meadows is about $177000 \mathrm{~km}^{2}$. Seagrass meadows are considered the most valuable/profitable ecosystems by Costanza et al. (1997) mainly because of their role in the nutrient cycle. They insure many other economical and/or ecological functions, such as: (1) providing habitats for fishes and shellfishes (Smith and Suthers, 2000), (2) scattering the energy

\footnotetext{
* Corresponding author.

E-mail address: s.dubois@epoc.u-bordeaux1.fr (S. Dubois).
}

of waves and stabilising sediments (Fonseca and Fisher, 1986; Madsen et al., 2001; Widdows et al., 2008), (3) protecting coast from erosion (Terrados and Duarte, 2000), and (4) purifying coastal waters (Ward, 1987). Seagrasses net worldwide primary production averages $1012 \mathrm{gDW} \mathrm{m}^{-2} \mathrm{y}^{-1}$ against $365 \mathrm{gDW} \mathrm{m}^{-2} \mathrm{y}^{-1}$ for macroalgae and $128 \mathrm{gDW} \mathrm{m}^{-2} \mathrm{y}^{-1}$ for phytoplankton. It accounts for $12 \%$ of the net worldwide coastal primary production and about $1 \%$ of the oceanic global net primary production (Duarte and Chiscano, 1999). Moreover, seagrasses support vegetal epiphytes (micro- or macro-algae), which can be as productive as seagrasses themselves (Borowitzka et al., 2006). Seagrass meadows are also natural hotspots for carbon sequestration with an estimated global seagrass carbon sinks of 48 to 112 tons per year (Kennedy et al., 2010). Seagrass beds are directly or indirectly submitted to anthropogenic disturbances such as, increased turbidity, increased nutrient loads and mechanical damages (e.g. land reclamation, boating, dredging, fisheries; Green and Short 2003). Orth et al. (2006) identified several factors at global (e.g. climate change), regional (e.g. shifts in water quality) and local (e.g. increased loading of sediment, contaminants and nutrients) scales that caused seagrass losses in temperate and tropical regions. Moreover Waycott et al. (2009) underlined the worldwide acceleration of seagrass losses from a median decline of 0.9 (before 1940) to $7 \%$ of total surface area per year since 1990. They ranked seagrass habitats among the most threatened ecosystems on earth, together with coral reefs and mangroves. Seagrass loss substantially affects the biodiversity of associated flora 
and fauna (Duffy, 2006), which could induce strong impacts on food webs and water quality (Cardinale, 2011).

All micro- and macroscopic primary producers contribute to the pool of particulate organic matter (POM) together with continental inputs. POM plays a key role in ecosystem functioning and especially in trophic transfers because different primary producers and corresponding detritus are not usable to the same extent by primary consumers, depending on their biochemical composition (Grémare et al., 1997; Tenore and Dunstan, 1973). Potential sources of POM are multiple and diversified: detrital matter, inputs from watersheds, seagrasses, benthic macroalgae, microphytobenthos, phytoplankton, epiphytes. Because of their physiology and of the origin of their nutrient resources, different primary producers usually exhibit different isotopic and/or elemental signatures. As a consequence, these signatures represent useful tracers to quantify their relative contribution to the composition of suspended particulate and sedimentary organic matter (SPOM and SOM, respectively, Cifuentes et al., 1988; Jaschinski et al., 2008; Machás and Santos, 1999), as well as to the food resources of primary consumers (Carlier et al., 2007; Riera et al., 1996; Schaal et al., 2008). Stable isotopes and elemental ratios have been widely used to identify which primary producers contribute to sediments organic matter, (e.g. Cifuentes et al., 1988; Fahl and Stein, 1997; Graham et al., 2001; Papadimitriou et al., 2005; Perdue and Koprivnjak, 2007; Ramaswamy et al., 2008). Many studies have focused on estuaries where organic matter sources are well discriminated, mostly continental vs. oceanic end-members (e.g. Cifuentes et al., 1988; Liu et al., 2006; Papadimitriou et al., 2005; Ramaswamy et al., 2008; Zhou et al., 2006). Conversely, only few studies have dealt with the composition of sediment organic matter in intertidal mudflats (Freese et al., 2008; Liu et al., 2006; Ramaswamy et al., 2008; Volkman et al., 2007; Yamamuro, 2000) and even less with seagrass meadows (Jaschinski et al., 2008; Kennedy et al., 2004; Moncreiff et al., 1992).

In Arcachon Bay - a coastal lagoon that shelters the largest seagrass meadow of Zostera noltii in Europe, with $70 \mathrm{~km}^{2}$ of seagrasses over the $115 \mathrm{~km}^{2}$ of the intertidal area (Auby and Labourg, 1996) - the surface area of $Z$. noltii beds has declined by 33\% between 1988 and 2008, and more markedly during the 2005-2008 period (Plus et al., 2010). This could lead to a change in the composition and amount of sedimentary organic matter, which could induce changes in food web complexity. The presence of several different settlements as schorres, channels, intertidal mudflats or seagrass meadows in this bay associated with the presence of a wide diversity of primary producers - phanerogams (e.g. $Z$. noltii, Z. marina, Spartina spp.), benthic macroalgae, microphytobenthos, phytoplankton, epiphytes - suggests that sediment organic matter could be composed of a wide mixture of primary producers and may exhibit a large spatial variability. Moreover, Arcachon Bay is strongly impacted by oceanic and continental inputs depending on season and/or location. Up to now, this impact has been noticed at several levels: (1) hydrology through a gradient of waters, which allows for the distinction of three water masses with distinct characteristics (Bouchet, 1993), (2) nutrient distribution, (3) phytoplankton abundance and composition (Glé et al., 2008), (4) zooplankton community structure and distribution (Vincent et al., 2002), (5) benthic macrofauna structure (Blanchet et al., 2004), and (6) trophic diet of some species such as the bivalve Ruditapes philippinarum (Dang et al., 2009). Finally, the large water volumes circulating through the entrance of the bay during each tide (between 130 and $400.10^{6} \mathrm{~m}^{3}$ ) and wind regimes associated with shallow depths lead to resuspension processes, which could affect the composition of SOM. This leads to the question of the origin and spatial distribution of sediment organic matter in such an ecosystem characterised by a high number and diversity of primary producers and POM sources. This question has not been tackled so far although SOM in the Arcachon Bay represents a major potential food source for benthic macrofauna.

To understand organic matter flows from primary producers to primary consumers, it is essential to first investigate SOM origin and spatial distribution. Indeed, and depending on spatial location, sediment composition can be affected by various factors like freshwater inputs or resuspension. Consequently a different composition of organic matter can be expected in relation to a different origin of this matter and according to spatial location. The specific aims of the present study were: (1) to determine isotopic and elemental signatures of potential sources, (2) to compare these signatures with those of sediment organic matter in order to (3) estimate the relative contribution of each primary producer to SOM composition, and finally (4) to investigate the spatial variability of sources and SOM characteristics in order to determine its environmental forcing.

\section{Material and methods}

\subsection{Study site}

The study was carried out in Arcachon Bay $\left(44^{\circ} 40^{\prime} \mathrm{N}, 1^{\circ} 10^{\prime} \mathrm{W}\right)$, a macrotidal (tidal amplitude: 0.8-4.6 m) semi-enclosed lagoon of $174 \mathrm{~km}^{2}$ located in south-western France (Fig. 1). This coastal ecosystem receives ocean water through a narrow channel located in the Southwest and riverine water from: (1) the Leyre River $(73 \%$ of river water inputs; Plus et al., 2010) and (2) several small streams located in the north-eastern and southern part of the bay (Fig. 1). Annual riverine water input amounts ca. $1.10^{9} \mathrm{~m}^{3}$. In the inner lagoon $\left(156 \mathrm{~km}^{2}\right)$, tidal channels $\left(41 \mathrm{~km}^{2}\right)$ separate large intertidal areas $\left(115 \mathrm{~km}^{2}\right)$ covered by the largest European $Z$. noltii meadow $\left(70 \mathrm{~km}^{2}\right)$. Water depth ranges between 0 and $20 \mathrm{~m}$. Arcachon bay displays a high variety of potential organic matter sources. Autochthonous primary macroproducers are not only composed of the currently declining intertidal Z. noltii seagrass but also include several other phanerogams - e.g. Zostera marina in subtidal channels and Spartina spp. on the shore and macroalgae - mainly belonging to the Gracilariale and Ulvale orders - of much lower biomass. The extent of intertidal mudflats $\left(63 \mathrm{~km}^{2}\right)$ enhances microphytobenthic production. Phytoplankton is another main autochthonous primary producer (Glé et al., 2008). At last, Arcachon Bay also receives continental organic matter - mainly composed of soil and litters of terrestrial C3 plants (Polsenaere et al., submitted for publication).

\subsection{Sample collection, processing and storage}

\subsubsection{Sampling}

During April 2009, 31 benthic stations located in the inner bay were sampled for sediment and/or primary producer characteristics (Fig. 1). Twelve stations were subtidal and located within major and minor channels. Nineteen stations were intertidal and distributed over a wide range of density of $Z$. noltii. Intertidal benthic stations were sampled at low tide. Subtidal benthic stations were sampled either at low or high tide. Four pelagic stations located along a gradient from the inner to the outer bay were sampled during high tide for characteristics of suspended particulate organic matter (SPOM). Two river stations and one terrestrial station were sampled for characteristics of continental primary producers and/or SPOM.

Intertidal collection: The top first centimetre of the sediment was collected by scrapping (1) $140 \mathrm{~cm}^{2}$ for sediment organic carbon and nitrogen (SOC and SON, respectively) elemental and isotopic composition, (2) $400 \mathrm{~cm}^{2}$ for microphytobenthos, and (3) by punching $5 \times 7.5 \mathrm{~cm}^{2}$ for chlorophyll $a$. Sediment was collected by punching $7.5 \mathrm{~cm}^{2}$ of the top $3 \mathrm{~cm}$ for granulometry. Three (granulometry) to five (other parameters) replicates were collected at each station. Macrophytes (macroalgae, phanerogams) and their associated epiphytes were collected by hand at each station when present.

Subtidal collection: Subtidal samples were collected by SCUBA diving. The top first centimetre was collected using three aluminium cores ( $80 \mathrm{~mm}$ of diameter) for SOC, SON and stable isotopes. The top first centimetre of five plastic cores (31 mm of diameter) and 


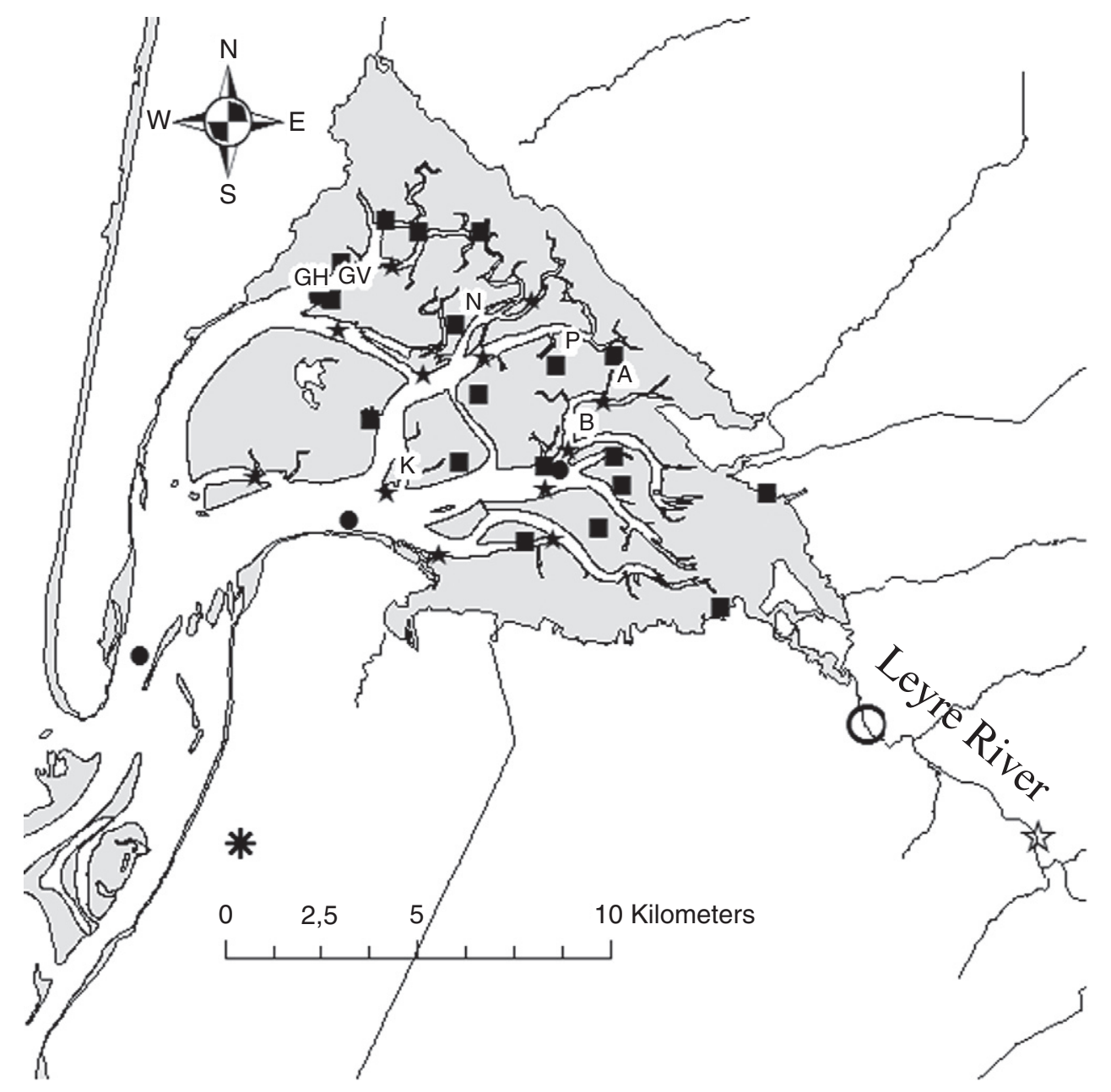

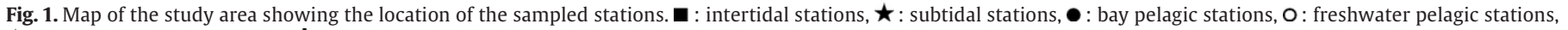
负: freshwater benthic station, * : terrestrial stations.

the top $3 \mathrm{~cm}$ of another plastic core were sampled for chlorophyll $a$ and granulometry, respectively.

Seawater collection: Seawater was collected $1 \mathrm{~m}$ below the surface using a Niskin bottle. It was collected within the scope of the French Coastal Monitoring Network SOMLIT (http://somlit.epoc.u-bordeaux1. $\mathrm{fr} / \mathrm{fr} /$ ) except the northern pelagic station, which was specific to the present study.

Continental collection: Freshwater macrophytes and terrestrial plants were collected by hand for organic carbon and nitrogen elemental and isotopic compositions. Freshwater was collected $10-20 \mathrm{~cm}$ below surface using plastic containers at a station located on the Leyre River.

\subsubsection{Sample processing and storage}

Back to the laboratory sediment samples for SOC and SON elemental and isotopic compositions and for granulometry were stored at $20{ }^{\circ} \mathrm{C}$. Sediment for chlorophyll $a$ was sieved on a $500 \mu \mathrm{m}$ mesh and stored at $-80{ }^{\circ} \mathrm{C}$. Microphytobenthos (epipelic diatoms) was extracted following the method of cell migration through nets (100 $\mu \mathrm{m}$ mesh size; Riera et al. (1999) as modified by Herlory et al. (2007)).

Macrophytes (macroalgae, phanerogams and terrestrial plants) were cleaned in two successive filtered-seawater baths to remove detritus and attached animals. When present, epiphytes were carefully scraped with a scalpel blade and stored at $-20^{\circ} \mathrm{C}$. Cleaned macrophytes were rinsed with Delonized Water (DIW) to remove salt and then stored at $-20^{\circ} \mathrm{C}$.
Seawater and freshwater samples were gently filtered through GF/ F filters for chlorophyll $a$, suspended particulate matter (SPM, preweighted and pre-combusted filters), suspended particulate organic carbon (SPOC) and nitrogen (SPON) elemental and isotopic compositions (pre-combusted filters). Filters for SPM were rinsed with ammonium formiate (bay stations) or DIW (river station) and dried overnight at $50{ }^{\circ} \mathrm{C}$. Filters for chlorophyll $a$ were stored at $-80^{\circ} \mathrm{C}$. Filters for SPOC and SPON elemental and isotopic composition were dried overnight at $50{ }^{\circ} \mathrm{C}$, and then stored in a dark dessicator at room temperature.

\subsection{Sample processing and analysis}

All frozen samples were freeze-dried before further processing, except sediments for grain-size analysis, which were defrozen at room temperature and filters for chlorophyll $a$, which were directly processed.

Sediment grain-size was assessed using a Malvern ${ }^{\circledR}$ Mastersizer Sizer laser microgranulometer.

Chlorophyll $a$ was extracted from sediment and filters with $90 \%$ acetone (final concentration) and fluorescence was measured using a Turner Designs TD-700 fluorimeter (Yentsch and Menzel, 1963).

Suspended particulate matter was determined gravimetrically.

Filters for particulate organic carbon and nitrogen elemental and isotopic compositions (SPOM and microphytobenthos) were decarbonated using $\mathrm{HCl}$ vapours. Filters for SPOC and SPON concentration were analysed using a Flash Elemental Analyser Series 1112 (ThermoFinnigan ${ }^{\circledR}$ ). Filters for SPOC and SPON isotopic 
compositions were scrapped and poured into tin cups. Sediment for SOC and SON elemental and isotopic composition was sieved on a $500 \mu \mathrm{m}$ mesh and powdered using a pestle and a mortar. Macrophytes were powdered using a ball mill. Sediment and macrophyte powders were weighed into tin cups for $\mathrm{N}$ elemental and isotopic compositions. For $\mathrm{C}$ elemental and isotopic compositions, powder was weighed into silver cups and decarbonated using $1.2 \mathrm{~N} \mathrm{HCl}$ (Kennedy et al., 2005). Cup samples were then analysed for $\mathrm{C}$ or $\mathrm{N}$ elemental and isotopic compositions using an elemental analyser (EA; NC2500, CarloErba $\left.{ }^{\circledR}\right)$ coupled with an isotope ratio mass spectrometer (IRMS; Isoprime, GV Instruments ${ }^{\circledR}$ ). IRMS daily drift was monitored using home-made standards (caseine, glycine) and, if necessary, data were corrected consequently. Elemental composition was calibrated against acetanilide and isotopic composition against homemade standards and reference material (IAEA-N2).

All isotopic data were expressed in the conventional delta notation (\%): $\delta^{13} \mathrm{C}_{\text {sample }}$ or $\delta^{15} \mathrm{~N}_{\text {sample }}=\left(\mathrm{R}_{\text {sample }} / \mathrm{R}_{\text {reference }}-1\right) \times 1000$ with $\mathrm{R}={ }^{13} \mathrm{C} /{ }^{12} \mathrm{C}$ or ${ }^{15} \mathrm{~N} /{ }^{14} \mathrm{~N}$, and the reference is PDB for $\delta^{13} \mathrm{C}$ and atmospheric $\mathrm{N}_{2}$ for $\delta^{15} \mathrm{~N}$. Analysis uncertainty was less than $0.2 \%$.

\subsection{In situ degradation experiment of $Z$. noltii}

Since Z. noltii is the main macrophyte in the Arcachon Bay, a oneyear in situ degradation experiment was carried out to account for possible isotopic and elemental fractionation during degradation. Results will be detailed elsewhere. Briefly put a decrease of $2.2 \%$ o in $\delta^{15} \mathrm{~N}$, an increase of $0.7 \%$ in $\delta^{13} \mathrm{C}$ and an increase of $3.1 \mathrm{~mol}$ $\mathrm{mol}^{-1}$ in $\mathrm{C} / \mathrm{N}$ ratio were recorded. These fractionations were taken into account for estimating the isotopic and elemental signature of degraded phanerogams.

\subsection{Mixing model}

A mixing model, including a Bayesian approach (package SIAR: Stable Isotope Analysis in R; Parnell et al., 2010) running with R.2.12.0 (R development team, 2010), was used to quantify the relative contributions of primary producers to the composition of sediment organic matter. The greatest advantage of this procedure is the incorporation of uncertainty linked to sources, consumers and trophic enrichment factors within the model (Parnell et al., 2010). This leads to the inclusion of an overall residual error term and to the generation of potential dietary solutions as true probability distributions. Three variables $\left(\delta^{15} \mathrm{~N}, \delta^{13} \mathrm{C}\right.$ and $\mathrm{N} / \mathrm{C}$ ratio) were used and six sources were considered (Gracilaria spp., Ulvales, decayed phanerogams, microphytobenthos, phytoplankton and river SPOM).

\subsection{Statistical analysis}

$\mathrm{C} / \mathrm{N}, \delta^{13} \mathrm{C}$ and $\delta^{15} \mathrm{~N}$ values of each primary producer and organic matter source were used to identify the main groups of primary producers and organic matter sources. Data were first normalised and a similarity matrix based on Euclidean distances was produced and later processed using cluster analysis (group average method). The groups identified by the cluster analysis were tested using the SIMPROF procedure (Clarke and Warwick, 2001).

Some primary producers (Z. noltii, Gracilaria spp. and microphytobenthos) were found at a large spatial scale within the Arcachon Bay. The variability of their isotopic signatures and the variability of SOM isotopic signatures were investigated at the system space scale. Especially, the possible effect of concentration of chlorophyll $a$, percentage of silts and clays, salinity, current speed and percentage of emersion on these variabilities was tested using the BIOENV procedure (Clarke and Warwick, 2001). Salinity, current speed and percentage of emersion were derived from the hydrodynamic MARS-model developed by Plus et al. (2009).
ANOSIM (ANalysis Of SIMilarity) tests were performed to test the effect of habitats: subtidal (S), intertidal covered by Z. noltii (I+Z.n.) and intertidal without Z. noltii (I - Z.n.) on sediment organic matter composition (Clarke and Warwick, 2001). These analyses were performed using PRIMER v.6.

Non-parametric Kruskal-Wallis tests were performed to assess significant univariate differences between subtidal sediments, sediments covered by $Z$. noltii and sediments without $Z$. noltii (STATISTICA 7).

\section{Results}

\subsection{Main characteristics of primary producers}

Isotopic signatures of primary producers ranged from $-4.2 \%$ (Pinus pinaster) to $11.7 \%$ (Spartina spp. epiphytes) for $\delta^{15} \mathrm{~N}$, and from $-38.6 \%$ (Cladophora sp., river macroalgae) to $-9.4 \%$ (Z. marina) for $\delta^{13} \mathrm{C}$ (Fig. 2A). There was a clear discrimination in $\delta^{13} \mathrm{C}$ between continental primary producers $\left(\delta^{13} \mathrm{C}<-25 \%\right.$ ) and Arcachon Bay primary producers $\left(\delta^{13} \mathrm{C}>-25 \%\right.$, Fig. $\left.2 \mathrm{~A}\right)$. $\mathrm{C} / \mathrm{N}$ ratio of primary producers ranged from $6.5 \mathrm{~mol} \mathrm{~mol}^{-1}$ (phytoplankton) to $87 \mathrm{~mol} \mathrm{~mol}^{-1}(P$. pinaster, Fig. 2B).

Cluster analysis associated with a SIMPROF test based on isotopic values and $\mathrm{C} / \mathrm{N}$ ratios discriminated seven groups of primary producers (Fig. 2C). Two of them were continental: continental plants (Pteridium sp. and P. pinaster), Quercus sp. leaves and river SPOM (group 1) on the one hand, and river macroalgae (group 2), on the other hand. Group 3 gathered all seagrass species plus one seagrass epiphyte. Within-bay macroalgae were split into two groups: the first one was only composed of Gracilaria spp. together with one seagrass epiphyte (group 4) and the second one mainly gathered Ulvales (group 5) plus two Gracilaria spp. and two Rhodophytes. Finally, bay phytoplankton - defined as SPOM exhibiting POC/chla ratio lower than $200 \mathrm{~g} \mathrm{~g}^{-1}$ (Savoye et al. 2003 and references therein) - corresponded to group 6, whereas microphytobenthos plus one seagrass epiphyte corresponded to group 7. Average $\delta^{15} \mathrm{~N}, \delta^{13} \mathrm{C}$ and $\mathrm{C} / \mathrm{N}$ ratio values and corresponding standard deviations of each group are reported in table 1.

Spatial variability of the main primary producers (Z. noltii, Gracilaria spp. and microphytobenthos) was relatively low, taken into account the space scale. Indeed, the standard deviation of their $\delta^{13} \mathrm{C}$ and $\delta{ }^{15} \mathrm{~N}$ ranged between $0.4 \%$ and $1.7 \%$ and averaged $1.0 \%$. Moreover, this variability in isotopic signatures was not explained by any tested environmental parameters (BIOENV, $\mathrm{p}>0.05$; see Section 2.6).

\subsection{Main characteristics of sediment organic matter (SOM)}

Silt and clay contents (average \pm standard deviation) were usually lower in subtidal sediments $(24 \pm 23 \%)$ as compared with intertidal sediments (I+Z.n.: $47 \pm 11 \%$; I-Z.n.: $41 \pm 17 \%$; Table 2) whereas chlorophyll a concentration was highly variable (S: $5.4 \pm$ $6.9 \mu \mathrm{g} \mathrm{g}^{-1}$; I +Z.n.: $8.9 \pm 3.7 \mu \mathrm{g} \mathrm{g}^{-1}$; I-Z.n.: $15.5 \pm 15.6 \mathrm{~g} \mathrm{~g}^{-1}$; Table 2). Conversely, $\delta^{15} \mathrm{~N}, \delta^{13} \mathrm{C}$ and $\mathrm{C} / \mathrm{N}$ ratio of sediment organic matter appeared relatively homogeneous within each group of sediment and did not differ much between groups (Table 2, Fig. $3 \mathrm{~A}$ and B). Subtidal SOM indeed showed mean $\delta^{15} \mathrm{~N}, \delta^{13} \mathrm{C}$ and $\mathrm{C} / \mathrm{N}$ ratio of $4.4 \pm 0.4 \%$ o, $-20.5 \pm 1.4 \%$ and $10.9 \pm 1.3 \mathrm{~mol} \mathrm{~mol}^{-1}$, respectively (Table 2). $\delta{ }^{15} \mathrm{~N}, \delta^{13} \mathrm{C}$ and $\mathrm{C} / \mathrm{N}$ ratio of $\mathrm{I}+$ Z.n. SOM were $4.6 \pm$ $0.5 \%$ o, $\quad-18.6 \pm 0.7 \%$ and $10.6 \pm 1.1 \mathrm{~mol} \mathrm{~mol}^{-1}$, respectively (Table 2). I-Z.n. SOM showed mean $\delta^{15} \mathrm{~N}, \delta^{13} \mathrm{C}$ and $\mathrm{C} / \mathrm{N}$ ratio of $4.7 \pm 0.5 \%$, $-19.7 \pm 1.0 \%$ and $10.7 \pm 1.0 \mathrm{~mol} \mathrm{~mol}^{-1}$, respectively (Table 2).

Cluster analysis and SIMPROF test based on isotopic values and C/ $\mathrm{N}$ ratios did not discriminate any group of sediments (Fig. $3 \mathrm{C}$ ). The ANOSIM performed on these values showed that there was no significant difference between subtidal sediments, intertidal sediments with Z. noltii and intertidal sediments without Z. noltii (Global test, 
A

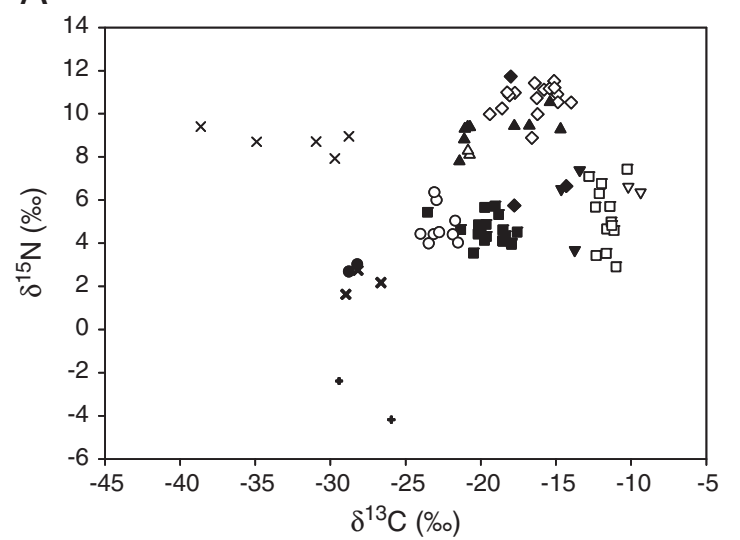

B

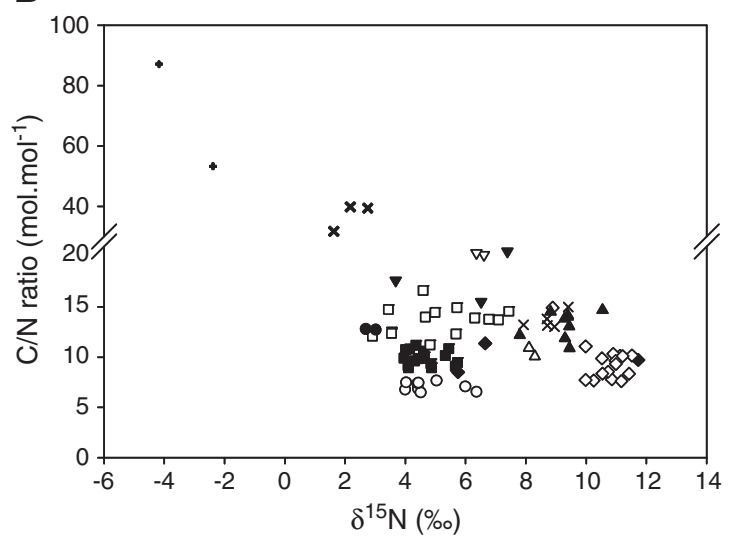

- Seagrass epiphytes $\diamond$ Gracilaria spp. $\Delta$ Rhodophytes $\square$ Microphytobenthos

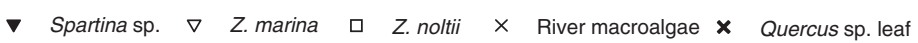

+ Higher plants $\bigcirc$ Bay phytoplankton $\quad$ River SPOM $\Delta$ Ulvales

C

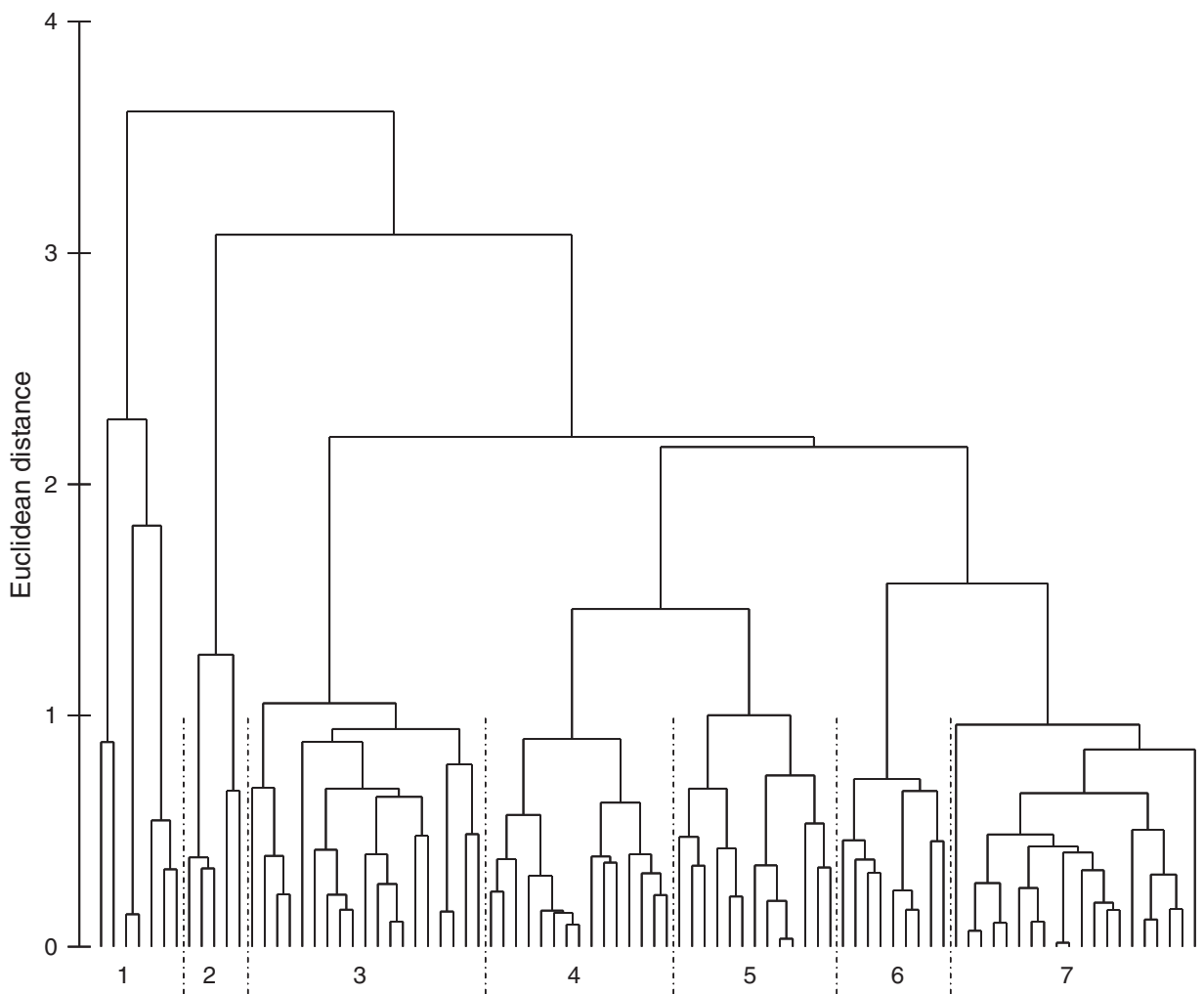

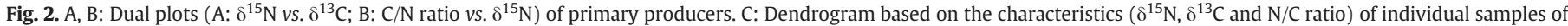

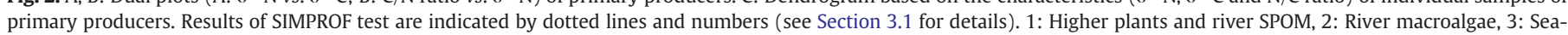
grasses, 4: Gracilaria spp., 5: Ulvales, 6: Bay phytoplankton, 7: Microphytobenthos.

$\mathrm{R}=0.049, \mathrm{p}>0.05)$. Nevertheless, pairwise tests performed within ANOSIM on groups of sediments, showed that subtidal sediments differed from $I+Z$.n. sediments $(R=0.156, p<0.05)$. Only $\delta^{13} C$ was significantly $(\mathrm{p}<0.05)$ different between subtidal sediments $(-20.5 \pm$ $1.4 \%$ ) and intertidal $Z$. noltii meadow $(-18.6 \pm 0.7 \%$ ). This difference was due to two subtidal stations (Fig. 3) located in the southern channel of the bay (stations B and K; Fig. 1). C/N ratios were also very homogeneous at the bay scale $\left(10.8 \pm 1.2 \mathrm{~mol} \mathrm{~mol}^{-1}\right)$ but with the exception of four stations that exhibited lower values, close to the phytoplankton $\mathrm{C} / \mathrm{N}$ ratio (Figs. 2, 3).

Possible effects of chlorophyll $a$ concentration, percentage of silts and clays, salinity, current speed and percentage of emersion on elemental and isotopic spatial variability of sediments were tested. None of these parameters either alone or in combination explained the variability of sediment isotopic and elemental signatures (BIOENV, p > 0.05).

\subsection{Composition of sediment organic matter}

Relative contribution of river SPOM and decayed phanerogams varied between kinds of sediments. River SPOM contributed more to subtidal sediments $(27 \pm 14 \%)$ than to intertidal bare sediments $(20 \pm 7 \%)$ and to intertidal sediments covered by $Z$. noltii $(14 \pm 6 \%)$. Decayed phanerogams contributed more to intertidal 
Table 1

Isotopic and elemental signatures of each group of primary producers. Groups (1 to 7) were determined by a SIMPROF test on a cluster analysis. 1: Terrestrial higher plants and river SPOM, 2: River macroalgae, 3: Seagrasses, 4: Gracilaria spp., 5: Ulvales, 6: Bay phytoplankton, 7: Microphytobenthos.(see Section 3.1 for details). SD: standard deviation; n: number of values.

\begin{tabular}{|c|c|c|c|}
\hline \multirow{2}{*}{$\begin{array}{l}\text { Primary } \\
\text { producers }\end{array}$} & $\delta^{15} \mathrm{~N}(\%)$ & $\delta^{13} \mathrm{C}(\%)$ & $\mathrm{C} / \mathrm{N}\left(\mathrm{mol} \mathrm{mol}^{-1}\right)$ \\
\hline & Mean \pm SD (n) & Mean \pm SD (n) & Mean \pm SD (n) \\
\hline \multicolumn{4}{|l|}{ Watershed } \\
\hline 1 & $0.8 \pm 2.9(7)$ & $-28.0 \pm 1.3(7)$ & $39.6 \pm 25.7(7)$ \\
\hline 2 & $8.7 \pm 0.6(5)$ & $-32.6 \pm 4.1$ & $13.6 \pm 0.8(5)$ \\
\hline \multicolumn{4}{|l|}{ Bay } \\
\hline 3 & $5.5 \pm 1.4(19)$ & $-11.9 \pm 1.4(19)$ & $15.0 \pm 2.9(19)$ \\
\hline 4 & $10.9 \pm 0.5(15)$ & $-16.5 \pm 1.7(15)$ & $9.0 \pm 1.0(15)$ \\
\hline 5 & $9.1 \pm 0.7(13)$ & $-18.8 \pm 2.6(13)$ & $12.8 \pm 1.7(13)$ \\
\hline 6 & $4.8 \pm 0.9(9)$ & $-22.7 \pm 0.8(9)$ & $7.1 \pm 0.4(9)$ \\
\hline 7 & $4.6 \pm 0.6(20)$ & $-19.4 \pm 1.4(20)$ & $10.0 \pm 0.9(20)$ \\
\hline
\end{tabular}

sediments covered by $Z$. noltii $(29 \pm 8 \%$ ) than to intertidal bare sediments $(23 \pm 8 \%)$ and to subtidal sediments $(22 \pm 6 \%)$. However there was no significant difference in the relative contribution of any primary producer between any groups of sediments (Friedman ANOVA on frequency distributions of results, $p>0.05$ ). Thus, at the bay scale, microphytobenthos contributed to the sediment organic matter for $19 \pm 3 \%$, bay phytoplankton for $20 \pm 12 \%$, degraded leaves of phanerogams for $25 \pm 8 \%$, river SPOM for $19 \pm 11 \%$ and finally macroalgae for $17 \pm 3 \%$ (Fig. 4). High standard deviations of bay phytoplankton, river SPOM and degraded leaves of phanerogams were mainly linked to several stations with a departure to the mean pattern of SOM compositions (results not showed). High contributions of river SPOM were recorded for stations B and $\mathrm{K}$ (57 and 46\%, respectively). Four stations exhibited high contributions of bay phytoplankton: 34, 36, 49 and $65 \%$ for stations $\mathrm{GH}, \mathrm{N}$, GV and A, respectively. Finally, one single station showed a higher contribution of decayed phanerogams: station P with 41\%.

\section{Discussion}

\subsection{Characteristics of primary producers and POM sources}

The use of carbon and nitrogen isotopic signatures, coupled with $\mathrm{C} / \mathrm{N}$ ratios, allowed to discriminate the main different groups of primary producers, especially macroalgae, phanerogams, microphytobenthos, phytoplankton and river SPOM. The isotopic signatures of each of these groups showed non-significant spatial variability and were in good agreement with those of previous studies in Arcachon Bay (Boschker et al., 2000; Dang et al., 2009; Schaal et al., 2008) with only few exceptions ( $\delta^{15} \mathrm{~N}$ of Gracilaria spp., and $\delta{ }^{13} \mathrm{C}$ and $\delta{ }^{15} \mathrm{~N}$ of $Z$. marina in Schaal et al., 2008) that may be due to difference in sampling season (February vs. April) and/or to the specificity of the sampling site (near a harbour in Schaal et al., 2008). Continental plants exhibited the lowest $\delta^{13} \mathrm{C}$ values because of the low $\delta^{13} \mathrm{C}$ of

\section{Table 2}

Characteristics of sediment and sediment organic matter (SOM) regarding the three groups of sediments: subtidal sediment (S) and intertidal sediment with (I+Z.n.) and without (I-Z.n.) Zostera noltii meadows.

\begin{tabular}{|c|c|c|c|}
\hline \multirow[t]{2}{*}{ Factors } & \multirow{2}{*}{$\frac{\text { Subtidal }(\mathrm{S})}{\text { Mean } \pm \text { SD }}$} & \multicolumn{2}{|l|}{ Intertidal (I) } \\
\hline & & $\mathrm{I}+$ Z.n. Mean \pm SD & $\mathrm{I}-$ Z. n. Mean \pm SD \\
\hline \multicolumn{4}{|l|}{ SOM } \\
\hline$\delta^{15} \mathrm{~N}(\%)$ & $4.4 \pm 0.4$ & $4.6 \pm 0.5$ & $4.7 \pm 0.5$ \\
\hline$\delta^{13} \mathrm{C}(\%)$ & $-20.5 \pm 1.4$ & $-18.6 \pm 0.7$ & $-19.7 \pm 1.0$ \\
\hline $\mathrm{C} / \mathrm{N}\left(\mathrm{mol} \mathrm{mol}^{-1}\right)$ & $10.9 \pm 1.3$ & $10.6 \pm 1.1$ & $10.7 \pm 1.0$ \\
\hline \multicolumn{4}{|l|}{ Sediment } \\
\hline Chlorophyll $a\left(\mu \mathrm{g} \mathrm{g}^{-1}\right)$ & $5.4 \pm 6.9$ & $8.9 \pm 3.7$ & $15.5 \pm 15.6$ \\
\hline Silts and clays (\%) & $24 \pm 23$ & $47 \pm 11$ & $41 \pm 17$ \\
\hline
\end{tabular}

their C-source (continental dissolved inorganic carbon for river macroalgae) or of their carboxylation pathway (sampled terrestrial plants are C3 plants). Conversely, marine and saltmarsh angiosperms exhibited the highest $\delta^{13} \mathrm{C}$ because their carboxylation pathway is close to C4 plants (Larkum et al., 2006). Isotopic values of $Z$. noltii and Spartina spp. were in the range of literature data (Boschker et al., 2000; Hemminga and Mateo, 1996; Kang et al., 1999, Machás and Santos, 1999; Machás et al., 2003).

Ulvales isotopic signatures were similar to those reported in other coastal systems (Dubois et al., 2007; Machás and Santos, 1999; Machás et al., 2003; Riera et al., 1996) even if their $\delta^{13} \mathrm{C}$ was higher in Arcachon Bay than in the Lapalme Lagoon (Carlier et al., 2007). Carlier et al. (2007) suggested that major inputs of dissolved inorganic carbon (DIC) had a significant impact on the $\delta^{13} \mathrm{C}$ values of some primary producers such as Ruppia cirrhosa. Continental DIC is indeed ${ }^{13} \mathrm{C}$-depleted compared to marine DIC (Fry and Sherr, 1984). The higher $\delta^{13} \mathrm{C}$ of Ulvales in Arcachon Bay may reflect either a more important ${ }^{13} \mathrm{C}$-depletion of DIC or higher continental inputs in the Lapalme Lagoon than in Arcachon Bay.

Microphytobenthos isotopic signature was in the range of, or even similar, to values reported for other coastal systems (Couch, 1989; Dubois et al., 2007; Jaschinski et al., 2008) but ${ }^{13}$ C-depleted compared to values found in Marennes-Oléron Bay (France, Riera et al., 1996, 1999) and in Ria Formosa lagoon (Portugal, Machás et al., 2003). Finally, phytoplankton isotopic signature in Arcachon Bay was typical of that of Western European temperate coastal systems (Carlier et al., 2007; Dubois et al., 2007; Jaschinski et al., 2008; Machás et al., 2003; Riera et al., 1996; Savoye et al., 2003).

Several studies have reported carbon and nitrogen isotopic and elemental values of primary producers in a (quasi-) exhaustive way in temperate systems, but none at an ecosystem space scale. Isotopic spectra of primary producers reported in the present study were in the same range than those from other coastal systems like the Marennes-Oléron Bay (Atlantic Ocean, France; Kang et al., 1999; Riera et al., 1996), the Bourgneuf Bay (Atlantic ocean, France; Decottignies et al., 2007), the Lapalme Lagoon (Mediterranean Sea, France; Carlier et al., 2007), the Kiel Fjord (Germany; Jaschinski et al., 2008) or the Gazi Bay (Kenya; Nyunja et al., 2009). Such broad spectra of isotopic and elemental values are actually typical of coastal areas where a large diversity of primary producers is encountered.

\subsection{Characteristics of sediment organic matter}

In contrast to what was expected, SOM signatures of the top first centimetre of sediments tended to be spatially homogeneous at the scale of the whole Bay. This suggests that particulate organic matters of different origins are resuspended and mixed before being redistributed over a large spacial scale probably because of wind-induced and/or tidal currents. An ongoing study on sediment dynamics within Arcachon Bay indicates that the top first centimetre of sediment within $\mathrm{Z}$. noltii meadow is resuspended in the course of a year (Ganthy, pers. com.). Concomitantly, there was no evidence of any spatial gradient of decreasing continental organic matter contribution from the Leyre river mouth towards the oceanic entrance of the Bay. Such high contribution of continental organic matter to coastal environment is usually indicated by low SOM $\delta^{13} \mathrm{C}$ (e.g. Liu et al., 2006, Ramaswamy et al., 2008), which was not found during the present study.

The only difference in SOM isotopic signatures was a lower $\delta^{13} \mathrm{C}$ of subtidal sediment as compared to sediments of $Z$. noltii meadows. This difference was due to two subtidal stations (Fig. 3) located in the southern channel of the Bay (stations B and K; Fig. 1). This difference could result from a larger contribution of continental POM input - continental POM is ${ }^{13} \mathrm{C}$-depleted (Fig. 2) - to the SOM of this southern channel, which is connected to the Leyre River. However, other 
A

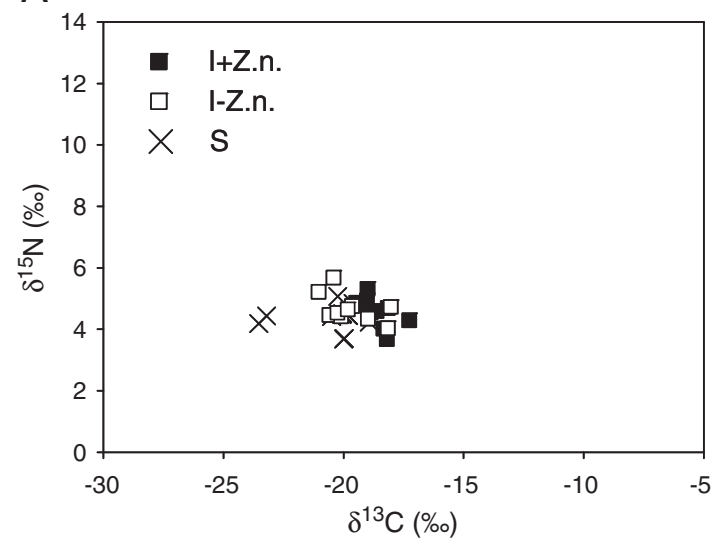

$\mathrm{B}$

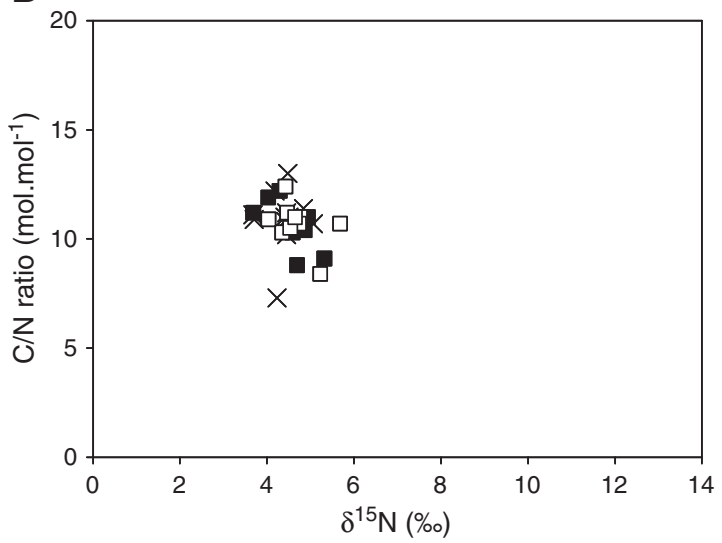

C

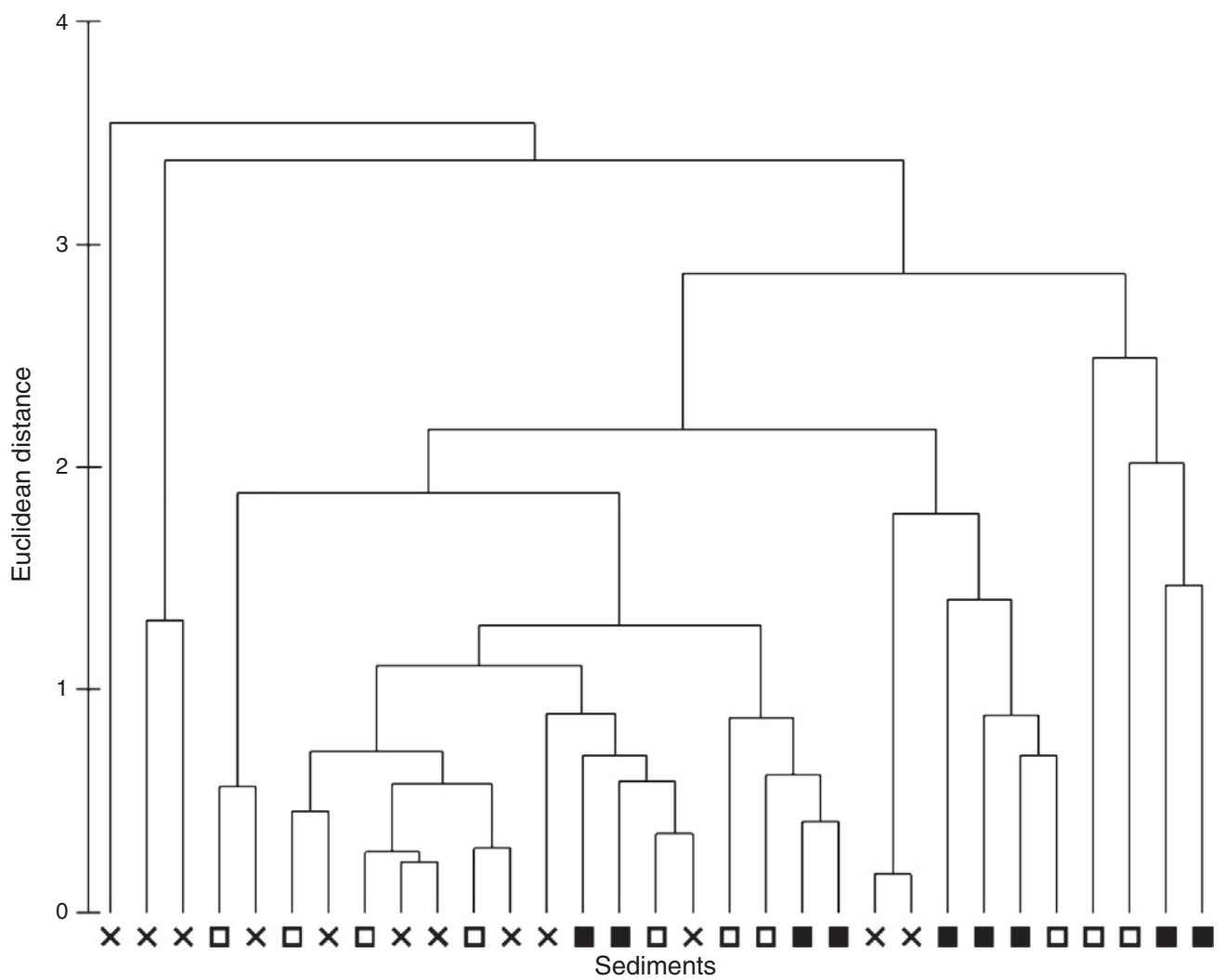

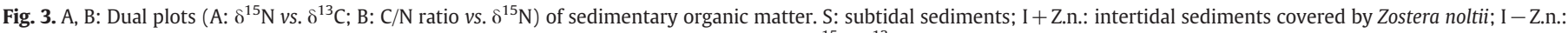
intertidal stations uncovered by Zostera noltii. C: Dendrogram based on the characteristics $\left(\delta^{15} \mathrm{~N}, \delta^{13} \mathrm{C}\right.$ and $\mathrm{N} / \mathrm{C}$ ratio $)$ of individual sedimentary organic matter samples.

subtidal stations located in the same channel did not exhibit peculiar $\delta^{13} \mathrm{C}$ values (stations CS, D and J; Fig. 1). Thus, in addition to continental POM inputs, the former stations may have the potential of accumulating this material, contrarily to the latter stations.

In Arcachon Bay, SOM $\delta{ }^{13} \mathrm{C}$ was in average ${ }^{13} \mathrm{C}$-enriched compared to most other coastal ecosystems (e.g. Liu et al., 2006; Ramaswamy et al., 2008). Values ranging from $-27.3 \%$ o to $-20.5 \%$ o have indeed been reported in these coastal (or estuarine or estuary-influenced) systems (Graham et al., 2001; Liu et al., 2006; Ramaswamy et al., 2008). Thus, Arcachon Bay - together with Marennes-Oléron Bay (Riera et al., 1996, 1999) - ranks within the highest values of that range. Here again, this suggests that Arcachon Bay is only weakly influenced by continental POM inputs.

SOM $\delta{ }^{15} \mathrm{~N}$ of Arcachon Bay ( $4.5 \pm 0.5 \%$ ) fits within the wide range of $\delta{ }^{15} \mathrm{~N}$ values already for coastal systems - from $1.6 \%$ in the
Western Mediterranean Sea (Papadimitriou et al., 2005) to $13.1 \%$ in the Delaware Estuary (Cifuentes et al., 1988). A large variability of SOM $\delta{ }^{15} \mathrm{~N}$ has been recorded as well within a given ecosystem (from 1.7\% to 7.8\% in the Yangtze Estuary (Liu et al., 2006); from $5 \%$ to $13.1 \%$ in the Delaware Estuary (Cifuentes et al., 1988)). Cifuentes et al. (1988) argued that high variability of $\delta^{15} \mathrm{~N}$ in the Delaware Estuary could result from sewage-derived $\mathrm{NH}_{4}^{+}$, which can be the source of ${ }^{15} \mathrm{~N}$-enriched particulate matter. Such a difference in $\delta{ }^{15} \mathrm{~N}$ values is often assigned to contrasting importance of anthropogenic impacts. Carlier et al. (2008) for example showed that the Canet Lagoon - which is strongly eutrophicated - exhibit a much more ${ }^{15} \mathrm{~N}$ enriched SOM $(10.5 \pm 0.4 \%$ ) compared to the Lapalme Lagoon $(3.7 \pm$ $0.9 \%$ ) - which is almost pristine. High $\delta^{15} \mathrm{~N}$ values due to anthropogenic inputs of N-nutrients were also recorded in other compartments such as SPOM, micro- and macrophytes, and consumers 


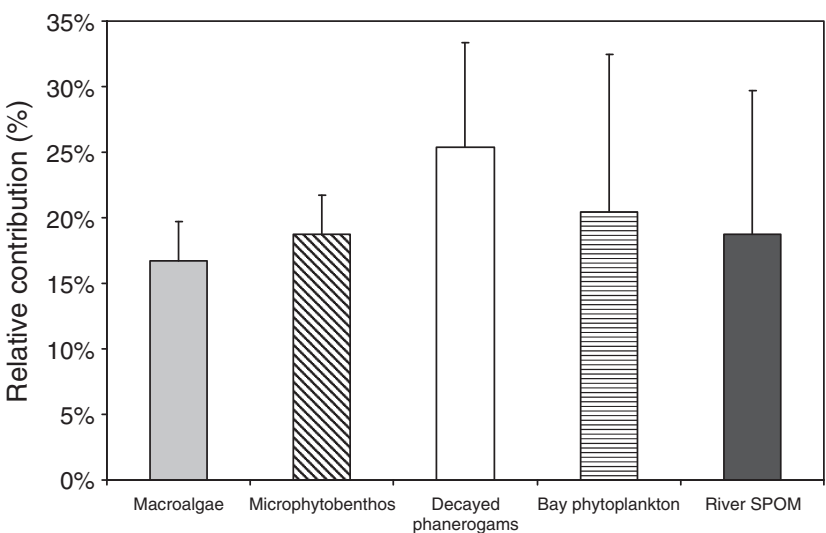

Fig. 4. Relative contributions of each group of primary producers to sedimentary organic matter in SOM (sedimentary organic matter). Vertical bars are standard deviations between stations and within the three types of stations mentioned above.

(McClelland and Valiela, 1998a,b; Middelburg and Herman, 2007; Riera et al., 2000). Such a spatial variability was not encountered in Arcachon Bay $\left(\delta^{15} \mathrm{~N}_{\mathrm{SOM}}=4.5 \pm 0.5 \% ; \delta^{15} \mathrm{~N}_{\text {phytoplancton }}=4.8 \pm 0.9 \%\right.$; $\delta{ }^{15} \mathrm{~N}_{\text {microphytobenthos }}=4.6 \pm 0.6 \%$ o) and $\delta{ }^{15} \mathrm{~N}$ values were closed to values indicative of pristine-like coastal areas. This indicates that Arcachon Bay is, comparatively to the above-cited ecosystems, weakly submitted to anthropogenic inputs of $\mathrm{N}$-nutrients. In fact waste water from the cities located around the Arcachon Bay are collected, treated and transported directly in the Atlantic ocean (i.e. not in the Arcachon Bay). In a study focused on nutrients in the rivers and streams of the Arcachon Bay, Canton et al. (2010) showed that only one small stream was enriched in anthropogenic ammonium because of an old dump. The present study shows that this input of anthropogenic ammonium has no effect on the SOM $\delta{ }^{15} \mathrm{~N}$ of the Arcachon Bay.

\subsection{Composition of sediment organic matter}

One of the aims of the present study was to evaluate the relative contribution of each kind of primary producers to Arcachon Bay SOM. In order to maximise the relevance of estimated contributions, it was necessary to limit the number of potential SOM sources considered in the mixing model (Phillips and Gregg, 2003). Some primary producers were therefore not included in the calculations. Especially, it was considered that continental macrophytes are not brought directly to the system but through riverine SPOM. Consequently only river SPOM was considered as a continental source. The five other groups of primary producers were used as determined by the SIMPROF of cluster analysis. Regarding seagrasses, elemental and isotopic fractionation associated with Z. noltii degradation (see Section 2.4) was taken into account: elemental and isotopic signatures of seagrasses were accordingly corrected before being used for mixing model calculations. Finally, five groups of potential SOM sources were considered for the mixing model (Fig. 5).

According to the mixing model estimations, the sediment organic matter of the top first centimetre was composed of $25 \%$ of decayed phanerogams, $19 \%$ of microphytobenthos, $20 \%$ of phytoplankton, $17 \%$ of macroalgae (Gracilaria spp. plus Ulvales) and 19\% of river SPOM, on average in the Arcachon Bay (Fig. 4). The contributions of microphytobenthos $(19 \pm 3 \%)$ and macroalgae $(17 \pm 3 \%)$ were very constant in the whole Bay, in contrast to the contributions of seagrasses ( $25 \pm 8 \%$ ), phytoplankton $(20 \pm 12 \%)$ and river SPOM ( $19 \pm 11 \%)$, which were more variable. The main departures to the mean pattern of SOM composition were found at two stations exhibiting low $\delta^{13} \mathrm{C}$ and at four stations exhibiting low $\mathrm{C} / \mathrm{N}$ ratios (Fig. 3). SOM of the former had a higher contribution of river SPOM (46-57\%) whereas SOM of the latter
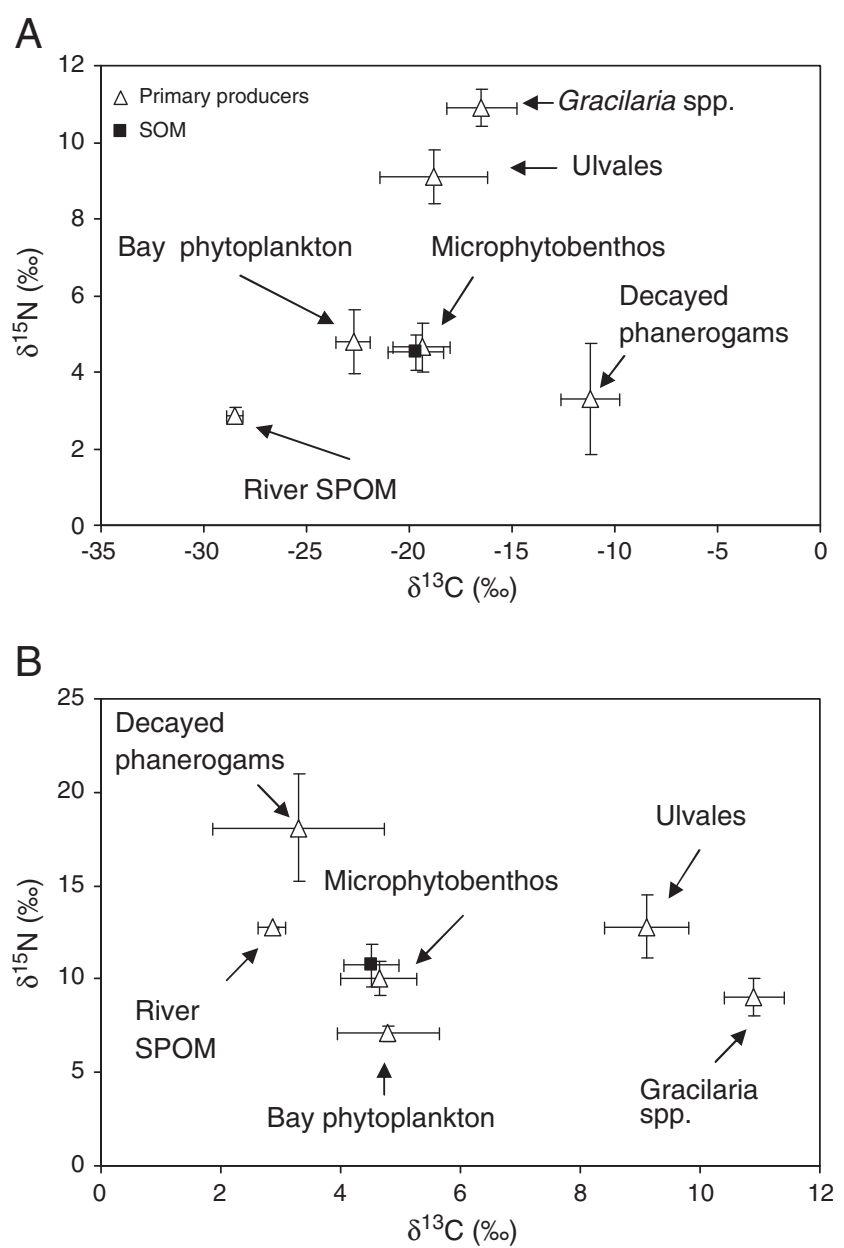

Fig. 5. A, B: Dual plots $\left(A: \delta^{15} \mathrm{~N}\right.$ vs. $\delta^{13} \mathrm{C}$, mean $\pm S D$; $: C / N$ ratio $v s . \delta^{15} \mathrm{~N}$, mean $\left.\pm S D\right)$ of sediments and primary producers considered for the stable isotope mixing model. SOM: sedimentary organic matter.

had a higher contribution of phytoplankton (34-65\%). Another exception is the high contribution of seagrasses to SOM at the station with the higher $\mathrm{C} / \mathrm{N}$ ratio (Fig. 3). The overall composition of sediment organic matter in Arcachon Bay illustrates the diversity of particulate organic matter sources in coastal systems. Autochthonous sources (phytoplankton, microphytobenthos, macroalgae and seagrasses) clearly dominated SOM composition in this system, in contrast to allochthonous SOM (river SPOM). Regarding autochthonous contributors, phanerogams represented a lower than expected contribution. Indeed Arcachon Bay shelters the largest seagrass meadow in Western Europe. Estimates of overall primary production at the Arcachon Bay scale based on production measurements (phytoplankton production: Glé et al., 2008), estimations of spatial coverage and biomass (seagrasses: Auby, 1991; Blanchet et al., 2004; Plus et al., 2010; salt marshes: Soriano-Serra, 1992; microphytobenthos: Escaravage et al., 1989; this study) and use of production to biomass ratios suggest that the production of phanerogams represents about 20 to $25 \%$ of total primary production within the Bay. Moreover, seagrasses are considered as more refractory material than macro- and microalgae (Godschalk and Wetzel, 1978, Rice and Tenore, 1981; Tenore and Dunstan, 1973; Wetz et al., 2008). Thus, this material is expected to accumulate within the sediment and to contribute to SOM at a higher level than suggested by computations based on primary production alone. This is not the case in Arcachon Bay, which suggests in that a large part of phanerogam production could be exported out of the Bay towards the open ocean and/or adjacent oceanic beaches. 
This hypothesis is supported by the worldwide synthesis made by Kennedy et al. (2010), which showed that only 30\% to 50\% of the net community production of seagrass meadows is buried in situ; the remaining being either consumed and/or exported (e.g., to closer bare sediments, beaches or to the deep sea). Such relatively low contributions of phanerogam organic matter to SOM were reported for other ecosystems where phanerogams are abundant: Hemminga et al. (1994) reported a 30\% seagrass (Thalassodendron ciliatum) contribution in the Gazi Bay (Kenya). Zhou et al. (2006) showed that SOM of Changjiang Estuary was composed of $31 \%$ of salt marsh plant material. Gacia et al. (2002) reported a contribution of about $28 \%$ of seagrass and its associated epibionts in Northeast Spain (Fanals point, Mediterranean Sea). Conversely, Volkman et al. (2007) showed that, in a mangrove system, SOM is dominated by phanerogam material. Finally, ecosystems where phanerogams make up large habitats, such as Arcachon Bay, are reputed to behave as net exporter of organic matter which is an important indirect role of coastal systems for the functioning of marine systems as a whole (Kathiresan and Bingham, 2001; Duarte, 1991).

\section{Summary and conclusions}

Our study aimed at estimating the composition of sediment organic matter using stable isotopes and $\mathrm{C} / \mathrm{N}$ ratios and at investigating the spatial variability of sediment characteristics at the ecosystem scale in a coastal macrotidal lagoon, the Arcachon Bay. With few exceptions, $\delta^{13} \mathrm{C}, \delta^{15} \mathrm{~N}$ and $\mathrm{C} / \mathrm{N}$ ratios of primary producers and sediment organic matter were homogeneously distributed over the bay, leading to a similarly homogeneous composition of SOM at the ecosystem scale. SOM was mainly of autochthonous origin. It was composed of $25 \%$ of decayed phanerogams, $19 \%$ of microphytobenthos, $20 \%$ of phytoplankton and $17 \%$ of macroalgae whereas river SPOM contributed to $19 \%$ of SOM composition. The main departures from this overall pattern were a high contribution of river SPOM (46-57\%) at two stations, a high contribution of phytoplankton (34-65\%) at four stations, and a high contribution of seagrasses (41\%) at a single station. The spatial variability of stable isotopes of the main primary producers and SOM, and of the $\mathrm{C} / \mathrm{N}$ ratio and composition of SOM was investigated in relation to potential environmental parameters (concentration of chlorophyll $a$, percentage of silts and clays, salinity, current speed and percentage of emersion). None of these parameters either alone or in combination explained the variability of primary producers and SOM characteristics. The following conclusions and hypothesis can be drawn: 1) SOM composition reflects the diversity of primary producers and particulate organic matter sources in the studied system; 2) SOM is mainly of autochthonous origin and a higher contribution of continental inputs is limited to few subtidal stations located in the Southern channel; 3) the low $\delta^{15} \mathrm{~N}$ of the main primary producers and SOM together with its homogeneous distribution within the Bay indicate that there is no significant influence of anthropogenic $\mathrm{N}$-sources in this system; 4) resuspension, mixing and redistribution of POM of different origins by windinduced and tidal currents in combination with shallow depths account for the overall homogeneity of SOM composition at the Bay scale; 5 ) this explains that none of the local (i.e. station-scale) environmental parameters nor a combination of them explained the low spatial variability of SOM characteristics.

\section{Acknowledgements}

We thank F. Prince and L. Letort, captain and crew member of R/V Planula IV. We also thank P. Lebleu, B. Gouilleux, A. Garcia, G. Meisterhans, F. Jude, N. Raymond, F. Garabetian, L. Bourrasseau, H. Bouillard, R. Parra, F. Salvo and C. Portier for help in field sampling and samples processing; G. Chabaud for performing sediment grain size analysis. This work was performed within the scope of the scientific programs
ORIQUART (EC2CO-PNEC), and ASCOBAR and OSCAR (Regional Council of Aquitaine; European Union).

\section{References}

Adam, P., 1990. Salt Marsh Ecology. Cambridge University Press, Cambridge.

Auby, I., 1991. Contribution à l'étude des herbiers de Zostera noltii dans le Bassin d'Arcachon: dynamique, production et dégradation, macrofaune associée. Thèse de doctorat en Ecologie. Université Bordeaux 1.

Auby, I., Labourg, P.-J., 1996. Seasonal dynamics of Zostera noltii hornem. In the bay of arcachon (France). Journal of Sea Research 35, 269-277.

Blanchet, H., De Montaudouin, X., Lucas, A., Chardy, P., 2004. Heterogeneity of macrozoobenthic assemblages within a Zostera noltii seagrass bed: diversity, abundance, biomass and structuring factors. Estuarine, Coastal and Shelf Science 61, 111-123.

Borowitzka, M.A., Lavery, P.S., van Keulen, M., 2006. Epiphytes of seagrasses. In: Larkum, A.W.D., Orth, R.J., Duarte, C.M. (Eds.), Seagrasses: Biology, Ecology and Conservation. Springer, Dordrecht.

Boschker, H.T.S., Wielemaker, A., Schaub, B.E.M., Holmer, M., 2000. Limited coupling of macrophyte production and bacterial carbon cycling in the sediments of Zostera spp. meadows. Marine Ecology Progress Series 203, 181-189.

Bouchet, J.-M., 1993. Stratifications, fronts halins dans une lagune mésotidale (Bassin

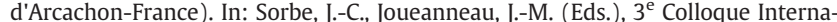
tional d'Océanographie du Golfe de Gascogne. Station Marine d'Arcachon, Arcachon, pp. 33-39.

Canton, M., Anschutz, P., Coynel, A., Polsenaere, P., Auby, I., Poirier, D., 2010. Nutrient export to an Eastern Atlantic coastal zone: first modeling and nitrogen mass balance. Biogeochemistry. doi:10.1007/s10533-010-9558-7.

Cardinale, B.J., 2011. Biodiversity improves water quality through niche partitioning. Nature 472, 86-89.

Carlier, A., Riera, P., Amouroux, J.-M., Bodiou, J.-Y., Escoubeyrou, K., Desmalades, M. Caparros, J., Grémare, A., 2007. A seasonal survey of the food web in the Lapalme Lagoon (northwestern Mediterranean) assessed by carbon and nitrogen stable isotope analysis. Estuarine, Coastal and Shelf Science 73, 299-315.

Carlier, A., Riera, P., Amouroux, J.-M., Bodiou, J.-Y., Desmalades, M., Grémare, A., 2008 Food web structure of two Mediterranean lagoons under varying degree of eutrophication. Journal of Sea Research 60, 264-275.

Cifuentes, L.A., Sharp, J.H., Fogel, M.L., 1988. Stable carbon and nitrogen isotope biogeochemistry in the Delaware estuary. Limnology and Oceanography 33 1102-1115.

Clarke, K.R., Warwick, R.M., 2001. Change in Marine Communities: An Approach to Statistical Analysis and Interpretation, 2nd edition. Plymouth, PRIMER-E.

Costanza, R., d'Arge, R., de Groot, R., Farber, S., Grasso, M., Hannon, B., Limburg, K. Naeem, S., O'Neill, R.V., Paruelo, J., Raskin, R., Sutton, P., van den Belt, M., 1997. The value of the world's ecosystem services and natural capital. Nature 387, 253-260.

Couch, C.A., 1989. Carbon and nitrogen stable isotopes of meiobenthos and their food resources. Estuarine, Coastal and Shelf Science 28, 433-441.

Dang, C., Sauriau, P.G., Savoye, N., Caill-Milly, N., Martinez, P., Millaret, C., Haure, J., de Montaudouin, X., 2009. Determination of diet in Manila clams by spatial analysis of stable isotopes. Marine Ecology Progress Series 387, 167-177.

Decottignies, P., Beninger, P.G., Rincé, Y., Robins, R.J., Riera, P., 2007. Exploitation of natural food sources by two sympatric, invasive suspension-feeders: Crassostrea gigas and Crepidula fornicata. Marine Ecology Progress Series 334, 179-192.

Duarte, C.M., 1991. Seagrass depth limits. Aquatic Botany 40, 363-377.

Duarte, C.M., Chiscano, C.L., 1999. Seagrass biomass and production: a reassessment. Aquatic Botany 65, 159-174.

Dubois, S., Jean-Louis, B., Bertrand, B., Lefebvre, S., 2007. Isotope trophic-step fractionation of suspension-feeding species: implications for food partitioning in coastal ecosystems. Journal of Experimental Marine Biology and Ecology $351,121-128$.

Duffy, J.E., 2006. Biodiversity and the functioning of seagrass ecosystems. Marine Ecology Progress Series 311, 233-250.

Escaravage, V., Garcia, M.E., Castel, J., 1989. The distribution of meiofauna and its contribution to detritic pathways in tidal flats (Arcachon Bay, France). Scientia Marina 52, 551-559.

Fahl, K., Stein, R., 1997. Modern organic carbon deposition in the Laptev Sea and the adjacent continental slope: surface water productivity vs. terrigenous input. Organic Geochemistry 26, 379-390.

Fonseca, M.S., Fisher, J.S., 1986. A comparison of canopy friction and sedimen movement between four species of seagrass with reference to their ecology and restoration. Marine Ecology Progress Series 29, 15-22.

Freese, E., Köster, J., Rullkötter, J., 2008. Origin and composition of organic matter in tida flat sediments from the German Wadden Sea. Organic Geochemistry 39, 820-829.

Fry, B., Sherr, E.B., 1984. $\delta^{13} \mathrm{C}$ measurements as indicators of carbon flow in marine and freshwater ecosystems. Contributions in Marine Science 27, 13-47.

Gacia, E., Duarte, C.M., Middelburg, J.J., 2002. Carbon and nutrient deposition in a Mediterrannean seagrass (Posidonia oceanica) meadow. Limnology and Oceanography 47, 23-32.

Glé, C., Del Amo, Y., Sautour, B., Laborde, P., Chardy, P., 2008. Variability of nutrients and phytoplankton primary production in a shallow macrotidal coastal ecosystem (Arcachon Bay, France). Estuarine, Coastal and Shelf Science 76, 642-656.

Godschalk, G.L., Wetzel, R.G., 1978. Decomposition of aquatic angiosperms. c. Zostera marina L. and a conceptual model of decomposition. Aquatic Botany 5, 329-354.

Graham, M.C., Eaves, M.A., Farmer, J.G., Dobson, J., Fallick, A.E., 2001. A study of carbon and nitrogen stable isotope and elemental ratios as potential indicators of source 
and fate of organic matter in sediments of the Forth Estuary, Scotland. Estuarine, Coastal and Shelf Science 52, 375-380.

Green, E.P., Short, F.T., 2003. World Atlas of Seagrasses. California University Press.

Grémare, A., Amouroux, J.M., Charles, F., Dinet, A., Riaux-Gobin, C., Baudart, J., Medernach, L., Bodiou, J.Y., Vétion, G., Colomines, J.C., Albert, P., 1997. Temporal changes in the biochemical composition and nutritional value of the particulate organic matter available to surface deposit-feeders: a two year study. Marine Ecology Progress Series 150, 195-206.

Hemminga, M.A., Slim, F.J., Kazungu, J., Ganssen, G.M., Nieuwenhuize, J., Kruyt, N.M., 1994. Carbon outwelling from a mangrove forest with adjacent seagrass beds and coral reefs (Gazi Bay, Kenya). Marine Ecology Progress Series 106, 291-301.

Hemminga, M.A., Mateo, M.A., 1996. Stable carbon isotopes in seagrasses: variability in ratios and use in ecological studies. Marine Ecology Progress Series 140, 285-298.

Herlory, O., Richard, P., Blanchard, G.F., 2007. Methodology of light response curves: application of chlorophyll fluorescence to microphytobenthic biofilms. Marine Biology 153, 91-101.

Jaschinski, S., Brepohl, D.C., Sommer, U., 2008. Carbon sources and trophic structure in an eelgrass Zostera marina bed, based on stable isotope and fatty acid analyses. Marine Ecology Progress Series 358, 103-114.

Kang, C.K., Sauriau, P.-G., Richard, P., Blanchard, G.F., 1999. Food sources of the infaunal suspension-feeding bivalve Cerastoderma edule in a muddy sandflat of MarennesOléron Bay, as determined by analyses of carbon and nitrogen stable isotopes. Marine Ecology Progress Series 187, 147-158.

Kathiresan, K., Bingham, B.L., 2001. Biology of mangroves and mangrove ecosystems Advances in Marine Biology, Book 40. Academic Press.

Kennedy, H., Gacia, E., Kennedy, D.P., Papadimitriou, S., Duarte, C.M., 2004. Organic carbon sources to SE Asian coastal sediments. Estuarine, Coastal and Shelf Science 60, 59-68.

Kennedy, P., Kennedy, H., Papadimitriou, S., 2005. The effect of acidification on the determination of organic carbon, total nitrogen and their stable isotopic composition in algae and marine sediment. Rapid Communications in Mass Spectrometry 19 $1063-1068$

Kennedy, H., Beggins, J., Duarte, C.M., Fourqurean, J.W., Holmer, M., Marbà, N., Middelburg J.J., 2010. Seagrass sediments as a global carbon sink: Isotopic constraints. Global Biogeochemical Cycles 24, GB4026. doi:10.1029/2010GB003848.

Larkum, A.W.D., Orth, R.J., Duarte, C.M., Larkum, A., Drew, E., Ralph, P., 2006. Photosynthesis and metabolism in seagrasses at the cellular level. In: Larkum, A.W.D., Orth, R.J., Duarte, C.M. (Eds.), Seagrasses: Biology, Ecology and Conservation. Springer, Dordrecht.

Liu, M., Hou, L.J., Xu, S.Y., Ou, D.N., Yang, Y., Yu, J., Wang, Q., 2006. Organic carbon and nitrogen stable isotopes in the intertidal sediments from the Yangtze Estuary, China. Marine Pollution Bulletin 52, 1625-1633.

Machás, R., Santos, R., 1999. Sources of organic matter in Ria Formosa revealed by stable isotope analysis. Acta Oecologica 20, 463-469.

Machás, R., Santos, R., Peterson, B., 2003. Tracing the flow of organic matter from primary producers to filter feeders in Ria Formosa lagoon, Southern Portugal. Estuaries and Coasts 26, 846-856.

Madsen, J.D., Chambers, P.A., James, W.F., Koch, E.W., Westlake, D.F., 2001. The interaction between water movement, sediment dynamics and submersed macrophytes. Hydrobiologia 444, 71-84.

Mann, K.H., 1973. Seaweeds: their productivity and strategy for growth. Science 182 975-981.

McClelland, J.W., Valiela, I., 1998a. Changes in food web structure under the influence of increased anthropogenic nitrogen inputs to estuaries. Marine Ecology Progress Series 168, 259-271.

McClelland, J.W., Valiela, I., 1998b. Linking nitrogen in estuarine producers to landderived sources. Limnology and Oceanography 43, 577-585.

Middelburg, J.J., Herman, P.M.J., 2007. Organic matter processing in tidal estuaries. Marine Chemistry 106, 127-147.

Moncreiff, C.A., Sullivan, M.J., Daehnick, A.E., 1992. Primary production dynamics in seagrass beds of Mississippi Sound: the contributions of seagrass, epiphytic algae, sand microflora, and phytoplankton. Marine Ecology Progress Series 87, 161-171.

Nyunja, J., Ntiba, M., Onyari, J., Mavuti, K., Soetaert, K., Bouillon, S., 2009. Carbon sources supporting a diverse fish community in a tropical coastal ecosystem (Gazi Bay, Kenya). Estuarine, Coastal and Shelf Science 83, 333-341.

Orth, R.J., Carruthers, T.J.B., Dennison, W.C., Duarte, C.M., Fourqurean, J.W., Heck Jr., K.L., Hughes, A.R., Kendrick, G.A., Kenworthy, W.J., Olyarnik, S., Short, F.T., Waycott, M. Williams, S.L., 2006. A global crisis for seagrass ecosystems. BioScience 56, 987-996.

Papadimitriou, S., Kennedy, H., Kennedy, D.P., Duarte, C.M., Marbá, N., 2005. Sources of organic matter in seagrass-colonized sediments: a stable isotope study of the silt and clay fraction from Posidonia oceanica meadows in the western Mediterranean. Organic Geochemistry 36, 949-961.

Parnell, A.C., Inger, R., Bearhop, S., Jackson, A.L., 2010. Source partitioning using stable isotopes: coping with too much variation. PLoS One 5, e9672.

Perdue, E.M., Koprivnjak, J.-F., 2007. Using the $\mathrm{C} / \mathrm{N}$ ratio to estimate terrigenous inputs of organic matter to aquatic environments. Estuarine, Coastal and Shelf Science 73, 65-72.
Phillips, D.L., Gregg, J.W., 2003. Source partitioning using stable isotopes: coping with too many sources. Oecologia 136, 261-269.

Plus, M., Dumas, F., Stanisière, J.-Y., Maurer, D., 2009. Hydrodynamic characterization of the Arcachon Bay, using model-derived descriptors. Continental Shelf Research 29, 1008-1013.

Plus, M., Dalloyau, S., Trut, G., Auby, A., de Montaudouin, X., Eric, E., Noël, C., Viala, C., 2010. Long-term evolution (1988-2008) of Zostera spp. meadows in Arcachon Bay (Bay of Biscay). Estuarine, Coastal and Shelf Science 87, 357-366.

Polsenaere, P., Savoye, N., Etcheber, H., Canton, M., Poirier, D., Bouillon, S., Abril, G., submitted for publication. Export and degassing of terrestrial carbon from small rivers and streams draining a temperate sandy podsolised catchment. Limnology and Oceanography.

Ramaswamy, V., Gaye, B., Shirodkar, P.V., Rao, P.S., Chivas, A.R., Wheeler, D., Thwin, S., 2008. Distribution and sources of organic carbon, nitrogen and their isotopic signatures in sediments from the Ayeyarwady (Irrawaddy) continental shelf, northern Andaman Sea. Marine Chemistry 111, 137-150.

Rice, D.L., Tenore, K.R., 1981. Dynamics of carbon and nitrogen during the decomposition of detritus derived from estuarine macrophytes. Estuarine, Coastal and Shelf Science 13, 681-690.

Riera, P., Richard, P., Grémare, A., Blanchard, G., 1996. Food source of intertidal nematodes in the Bay of Marennes-Oléron (France), as determined by dual stable isotope analysis. Marine Ecology Progress Series 142, 303-309.

Riera, P., Stal, L.J., Nieuwenhuize, J., Richard, P., Blanchard, G., Gentil, F., 1999. Determination of food sources for benthic invertebrates in a salt marsh (Aiguillon Bay, France) by carbon and nitrogen stable isotopes: importance of locally produced sources. Marine Ecology Progress Series 187, 301-307.

Riera, P., Stal, L.J., Nieuwenhuize, J., 2000. Heavy $\delta 15 \mathrm{~N}$ in intertidal benthic algae and invertebrates in the Scheldt estuary (The Netherlands): effect of river nitrogen inputs. Estuarine, Coastal and Shelf Science 51, 365-372.

Savoye, N., Aminot, A., Tréguer, P., Fontugne, M., Naulet, N., Kérouel, R., 2003. Dynamics of particulate organic matter $\delta^{15} \mathrm{~N}$ and $\delta^{13} \mathrm{C}$ during spring phytoplankton blooms in a macrotidal ecosystem (Bay of Seine, France). Marine Ecology Progress Series 255, 27-41.

Schaal, G., Riera, P., Leroux, C., 2008. Trophic coupling between two adjacent benthic food webs within a man-made intertidal area: a stable isotopes evidence. Estuarine, Coastal and Shelf Science 77, 523-534.

Smith, K.A., Suthers, I.M., 2000. Consistent timing of juvenil fish recruitment to seagrass beds within two Sydney estuaries. Marine and Freshwater Research 51, 765-776.

Soriano-Serra, E.-J., 1992. Etude écologique des marais salés du Bassin d'Arcachon: structure et évolution des schorres, production et dégradation de leur végétation et échanges de matières particulaires entre les schorres et le bassin. Thèse de Doctorat. Université Bordeaux 1.

Tenore, K.R., Dunstan, W.M. 1973. Comparison of rates of feeding and biodeposition of the american oyster, Crassostrea virginica Gmelin, fed different species of phytoplankton. Journal of Experimental Marine Biology and Ecology 12, 19-26.

Terrados, J., Duarte, C.M., 2000. Experimental evidence of reduced particle resuspension within a seagrass (Posidonia oceanica L.) meadow. Journal of Experimental Marine Biology and Ecology 243, 45-53.

Vincent, D., Luczak, C., Sautour, B., 2002. Effects of a brief climatic event on zooplankton community structure and distribution in Arcachon Bay (France). Journal of the Marine Biological Association of the United Kingdom 82, 21-30.

Volkman, J.K., Revill, A.T., Bonham, P.I., Clementson, L.A., 2007. Sources of organic matter in sediments from the Ord River in tropical northern Australia. Organic Geochemistry 38, 1039-1060.

Ward, T.J., 1987. Temporal variation of metals in the seagrass (Posidonia autralis) and its potential as a sentinel accumulator near a lead smelter. Marine Biology 95, 315-321.

Waycott, M., Duarte, C.M., Carruthers, T.J.B., Orth, R.J., Dennison, W.C., Olyarnik, S., Calladine, A., Fourqurean, J.W., Heck, K.L., Hughes, A.R., Kendrick, G.A., Kenworthy, W.J., Short, F.T., Williams, S.L., 2009. Accelerating loss of seagrasses across the globe threatens coastal ecosystems. Proceedings of the National Academy of Sciences $106,12377-12381$.

Wetz, M.S., Hales, B., Wheeler, P.A., 2008. Degradation of phytoplankton-derived organic matter: Implications for carbon and nitrogen biogeochemistry in coastal ecosystems. Estuarine, Coastal and Shelf Science 77, 422-432.

Widdows, J., Pope, N.D., Brinsley, M.D., Asmus, H., Asmus, R.M., 2008. Effects of seagrass beds (Zostera noltii and Z. marina) on near-bed hydrodynamics and sediment resuspension. Marine Ecology Progress Series 358, 125-136.

Yamamuro, M., 2000. Chemical tracers of sediment organic matter origins in two coastal lagoons. Journal of Marine Systems 26, 127-134

Yentsch, C.S., Menzel, D.W., 1963. A method for the determination of phytoplankton chlorophyll and pheophytin by fluorescence. Deep-Sea Res 10, 221-231.

Zhou, J., Wu, Y., Zhang, J., Kang, Q., Liu, Z., 2006. Carbon and nitrogen composition and stable isotope as potential indicators of source and fate of organic matter in the salt marsh of the Changjiang Estuary, China. Chemosphere 65, 310-317. 